\title{
ANMELDELSE
}

\section{Du skal forberede dig på at blive pensionist}

\author{
Lisbeth Theilgaard, Niels Møller \& Mads Christoffersen
}

Arbejdet forstået bagloens

- erfaringer fra 40 års arbejdsliv

Frydenlund, 2019, 293 sider

ISBN: 9788772162041

A

rbejdsmarkedet vil i de kommende år gennemgå dramatiske ændringer. Den største er uden tvivl, at en bestemt alder i sig selv ikke vil være ensbetydende med et farvel til arbejdslivet, sådan som det har været i generationer - lige så sikkert som et ammen i kirken. Når fløjten lød for sidste gang, forlod man ikke bare sin arbejdsplads fra den ene dag til den anden. Man forlod også de kolleger, der for de fleste havde været den sociale kerne gennem en menneskealder.

Vi ser allerede i dag, at mange flere i stedet vælger en glidende tilbagetrækning fra arbejdsmarkedet, og at flere faktisk fortsætter i jobbet til ind i 70'erne. Den trend vil blive forstærket i de kommende år. Og det kan jo virke som en besynderlig udvikling, når den offentlige debat først og fremmest er domineret af spørgsmålet om tidlig pension til de lønmodtagere, som hverken har kræfter eller helbred til at fortsætte helt frem til folkepensionsalderen.

Men lige præcis i den situation er der brug for at kaste et blik over skulderen og tale med nogle af de seniorer, der er gået ud ad porten for sidste gang. Fordi deres fortællin- ger og erfaringer kan gøre os meget klogere på, hvad der betyder mest i arbejdslivet, og hvilken betydning deres arbejde har haft for overgangen til livet som aktiv pensionist.

Netop det har Mads Christoffersen, Lisbet Theilgaard og Niels Møller kastet sig over i bogen "Arbejdet forstået baglæns - erfaringer fra 40 års arbejdsliv." Gennem en række workshops, eller mere rammende "fortidsværksteder", har bogens tre forfattere interviewet ikke færre end 128 mennesker, der repræsenterer vidt forskellige faggrupper, og som derfor også bidrager med lige så forskellige erfaringer fra et langt arbejdsliv.

Læger, sociologer, ingeniører, IT-folk, journalister, bankfolk, politifolk, teknikere, IT-folk, sosu'er, fabriksarbejdere og bygningsarbejdere er blandt dem, der har fortalt deres historie. På mange måder er det derved blevet til en bog om arbejdets historie i de sidste 40 år. Om fag og brancher der forsvandt. Om markante omvæltninger. Om en rivende teknologisk udvikling. Om globalisering. Og ikke mindst om en stadig mere internationaliseret ledelse på godt og ondt. Men mest det sidste.

Disse tidsbilleder giver nok stof til eftertanke, men rummer også en romantisering, som er stort set ikke-eksisterende på dagens arbejdsmarked. Meget er gået tabt. Kammeratskabet på den enkelte arbejdsplads først og 
fremmest. Firmaskovturen, fredagsbollerne eller fyraftensbajeren, som kun de sidste dages hellige endnu holder i hævd.

Var det blevet ved de mange - ganske vist underholdende - historier om gamle dage, ville bogen næppe have sat sig dybere spor. Men ved at koble de mange erfaringer sammen på tværs af fag, køn og brancher til en diskussion om den gode overgang fra arbejdsliv til pensionisttilværelsen, taler fortidsværkstederne lige ind i fremtidens seniorliv. Og her bliver det for alvor spændende.

Debatten om den glidende tilbagetrækning fra arbejdsmarkedet har stået forholdsvis højt på dagsordenen i de senere år. Godt hjulpet på vej af regeringens Seniortænketank, der for nylig kastede en række mere eller mindre konkrete forslag på bordet. Den debat gør pludselig "Arbejdet forstået baglæns" meget mere aktuel og relevant. Men også dejligt konkret.
Naturligvis kan vi gå ud og spørge de yngre, hvilket arbejdsliv de drømmer om som ældre. Men svarene vil næppe ligge lige på tungen. De kommer først med alderen og erfaringen. For mange er udsigten til seniorlivet truende, angstprovokerende og udfordrende med tab af identitet og ofte med et tab af det sociale fællesskab, der har fulgt én igennem et langt arbejdsliv.

Det skal vi lære at tale meget mere om. I samfundsdebatten og ikke mindst ude på den enkelte arbejdsplads. Kun ved at insistere på at tale om det, får vi hjulpet kommende pensionister til den bedste overgang til seniorlivet. Afslutningen i bogen er formuleret som otte gode råd til et godt seniorliv. Sammenfattet her i et enkelt: Du skal forberede dig på at blive pensionist. Jo bedre forberedt, des lettere bliver det at nyde friheden og de mange nye muligheder.

Anmeldt af Palle Smed, direktør i Faglige Seniorer

e-mail: ps@fagligsenior.dk 